\title{
"Smart Puzzle" Game Helping Children Learn to Read
}

\author{
Septyana Hardianti Yunanto \\ Information System Department \\ Faculty of Computer Science \\ Soegijapranata Catholic University, Semarang, Indonesia, 50234 \\ septyana93@gmail.com \\ T. Brenda Chandrawati, ST., MT., IPM \\ Information System Department \\ Faculty of Computer Science \\ Soegijapranata Catholic University, Semarang, Indonesia, 50234 \\ brenda@unika.ac.id
}

\begin{abstract}
The game is one of the media for learning. One of the games that can be used as media of instruction is "Smart Puzzle" games. "Smart Puzzle" games are educational games used as tools to teach reading to kindergarten with a game concept devised letters tailored to a different picture in each part. This game is divided into three categories, namely animal category which consists of 10 stages and 2 mini games, a profession category consists of 10 stages and 2 mini games and family categories that consist of 6 stages and 1 mini game. "Smart Puzzle" game has 4 components as a medium of instruction. The 4 componets are drafting letters, completing pictures, matching jobs with their workplace and learning family tree. With the 4 components of "Smart Puzzle" game, it can be compared to other reading games.
\end{abstract}

Keywords: game, puzzle, educational, learning, exercising, reading

\section{INTRODUCTION}

Reading becomes one of the most important things because reading makes persons develop their knowledge. If someone does not have reading skills, he/she will be self-defeating in gaining knowledge that should be acquired as a student who always learn reading and writing. The most important phase of reading for the child is between the ages of 5-9 years, but whether children can read at this age or not depends on the school and their behaviour towards reading [1].

Children must be trainned to read early in order to make them recognize and memorize the letters, as children's early reading skills are very favorable in terms of the teaching and learning process. One of them is learning to read early to fulfill the curiosity of children. They will speak, write, and understand your ideas better[2]. Children in kindergarten (TK) start to get knowledge on letters and numbers, and they have to memorize and recite the letters as well as numbers taught.

There are some children who have difficulty in reading and cannot memorize the letters properly due to themselves and the environment where they learn to read. Reading difficulty can interfere with children's learning activities. NAEYC (National Association for the Education of Young Children) recommends forms and methods to teach children to read at an early age, namely by introducing single letters, reading the alphabet, forming letters with lines that have already been provided [3]. The kindergarten teacher can use it for teaching while playing, singing and memorizing.

With the advancement of modern technology all learning can be done 
interestingly using games. Games are used to entertain the players, but now many games are developed into educational games. Kids nowadays are the "digital native" who have a sense that they were born in the digital era and digital equipment becomes part of their lives. The kids can adapt technology easily. It can be seen from their very good interaction with the technologies such as internet gaming, video games, and computer games [4]. Then, the writers want to make games that can help improve children' reading ability when they are on the bench due to KINDERGARTEN reading training so that they will remember the lessons delivered better. The games will be made with full of interesting images and colors that will attract players so that they will not bored.

\section{LITERATURE REVIEW}

\subsection{Reading}

In the Large Indonesian Language Dictionary (KBBI), reading is defined as the way individuals see and understand the content of what is written orally or just in their hearts. The definition of reading is an activity to match the right letter or pronounce written symbols [5]. There is another definition of reading that is a process carried out by the person to obtain the message conveyed by someone through a writing language [6]. Reading can help us be more insightful, be successful and have better lives [7].

\subsection{Game}

There is some meanings of the game according to the experts, [9] that is:

1. Ivan $C$ Sibero. According to Ivan $C$ Sibero, game is an application that is widely used and enjoyed by users of electronic media.

2. Fauzia. A Game is a form of entertainment that is usually used to refresh fatigue thoughts every day.

In other words, a game is an application that is widely used in everyday life and among the young, games are for entertaiments and refreshing their mind.

\subsection{Educational Game}

Educational Games are digital games made for education. Educational games can support the learning processespecially for early childhood [12]. Educational games with interactive media technology will help children to understand the content of the game. Aldrich [13] says in his book entitled ' Learning Online with Games, Simulations and Virtual Worlds', that there are five different genres of games that can be used for education. They are Educational Simulations, Serious Games, Frame Games, Class Games and Virtual World.

\subsection{Construct 2}

Construct 2 is a game-based technology HTML5 editor that actually is more directed to non-programmers to create games very easily through features of dragand-drop and behaviour-based logic system [11].

\section{RESEARCH METHODOLOGY AND GAME DEVELOPMENT}

\subsection{Library Study and Questionnaire}

Library study is used to collect some data that occur in the life of the community regarding the difficulty of reading in children. A questionnaire was distributed to 30 respondents consisting of 30 parents who have children that are in Kindergarten. The parents will bring in the children to play "Smart Puzzle".

\subsection{The Creation of the Electoral Game Engine and Gameplay}

The design of the gameplay is made as easy as possible so that the players have no trouble playing. Game engine used is Counstruct 2.

\section{3. $\quad$ Enter and Compile Games}

After accumulating assets, then go into the stage of preparation of the games in accordance with the gameplay already made.

\subsection{Testing Game}

At this stage the aim is that when the game is distributed, there are no bugs or 
errors in programming or drafting a player that can disrupt the game while playing. If the bug is still there then it needs to be repaired again. If there is no bug then the game is ready to be distributed to respondents.

\section{MAKING GAMES AND DISCUSSION}

\subsection{Making GUI "Smart Puzzle"}

\section{Game}

GUI (Graphical User Interface) is always observed in making the "Smart Puzzle" game in order to make it easier for players to play this game. "Smart Puzzle" is designed or made for kindergarten children as a medium of instruction, which allows children to play comfortably and easily. In the "Smart Puzzle" game election form font, font size and color are designed suitable for their age. The placement of menus, titles, button and backsound also note, to make it look neat and convenient to be seen as well as heard while playing the game of "Smart Puzzle". The GUI used in "Smart Puzzle" game as follows.

\section{A. Menu Splashscreen}

Display menu, Splashscreen is seen by the player when first opening Gaming "Smart Puzzle".

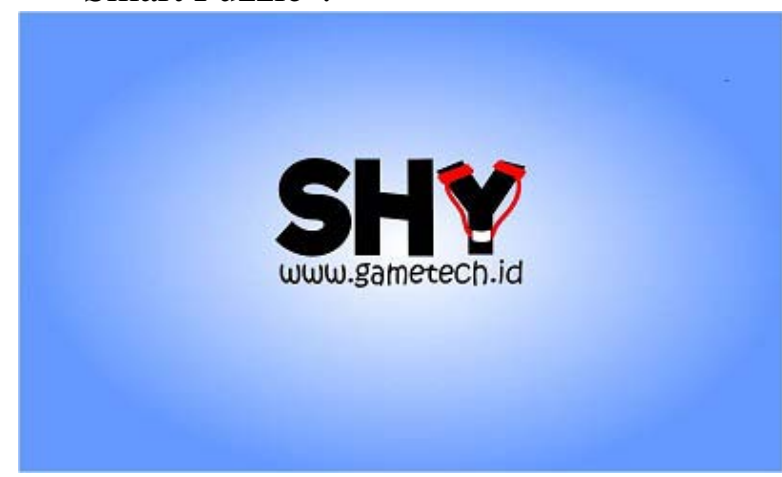

Figure 4.1GUI Display Menu Splashscreen

\section{B. Menu Loading}

The menu loading is the second appearance of the gaming "Smart Puzzle" which becomes the loading of the game.

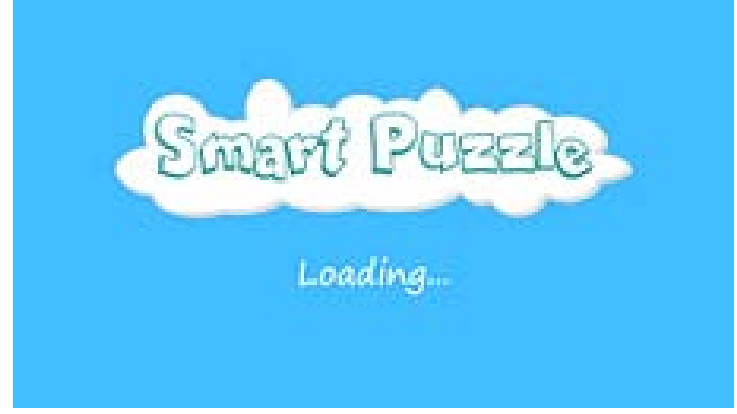

Figure 4.2GUI Display Menu Loading

\section{Main Menu}

The main menu on the "Smart Puzzle" game is the title of the game, the Start button to start the game and the settings button to enter the layer arrangements of this game.

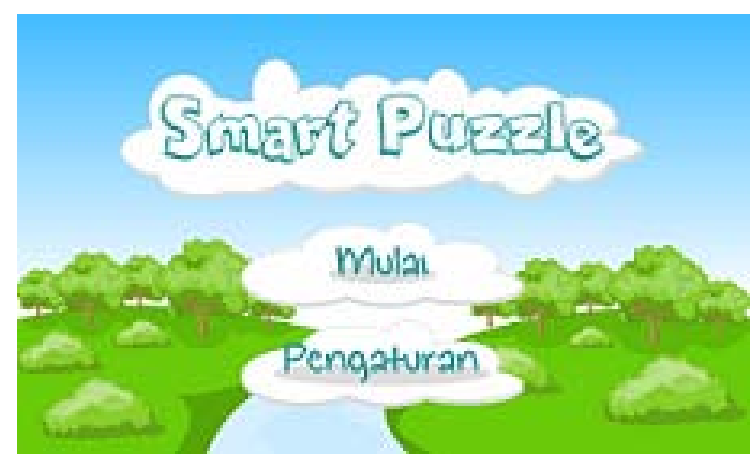

Figure 4.3 GUI Display Menu Utama

\section{Menu Settings}

The setting menu is the menu that is used to turn off and turn on the sound effects and backsound.

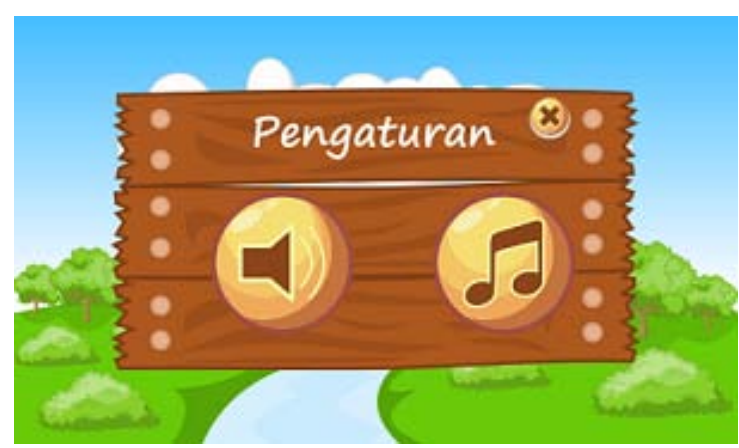

Figure 4.4 GUI Display Settings Menu

E. Menu Category Option

Category selection menu is a menu containing buttons category animals, key 
"Smart Puzzle" Game Helping Children Learn to Read

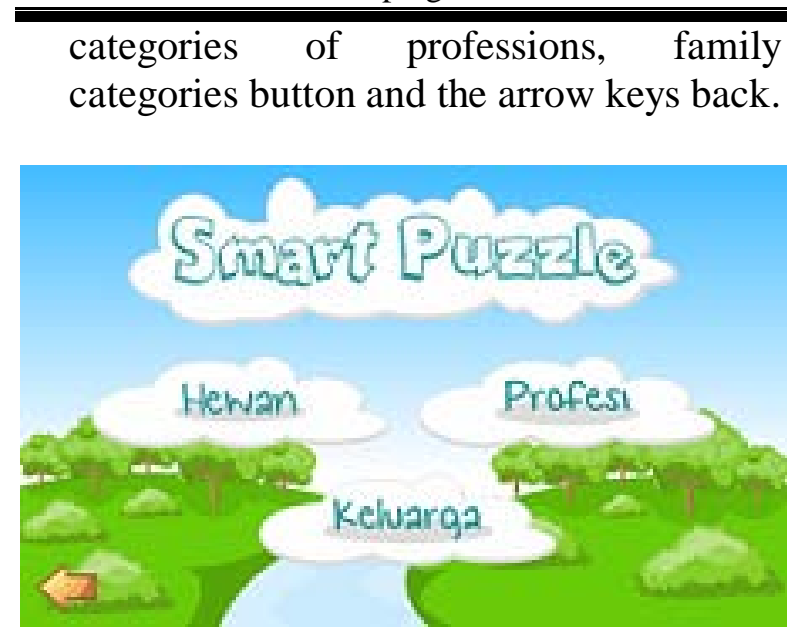

Figure4.5 GUI DisplayOptions Menu Category

\subsection{Gameplay "Smart Puzzle" game}

Appearance of the gameplay "Smart Puzzle" game is displayed when the game is played. the categories of animal, profession and family are use. The same gameplay is due to the fact that the play is still the same. Mini game profession and family are different from mini game for each mini game has a different problem. Here are some examples of the display of the gameplay on "Smart Puzzle" game, namely:

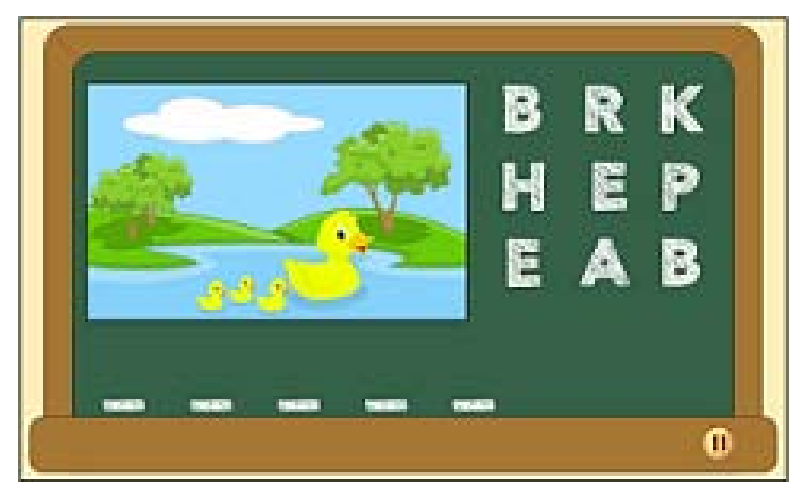

Figure 4.6 Gameplay Display Animal Category

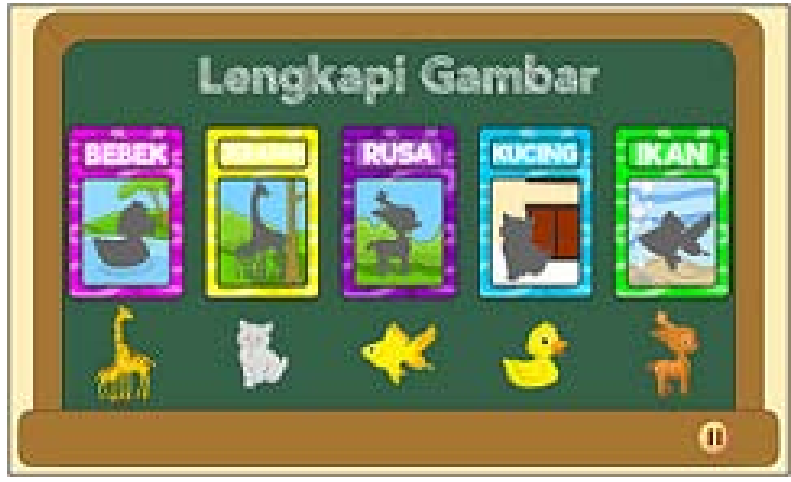

Figure 4.7 Gameplay Display Mini Game Animal Category

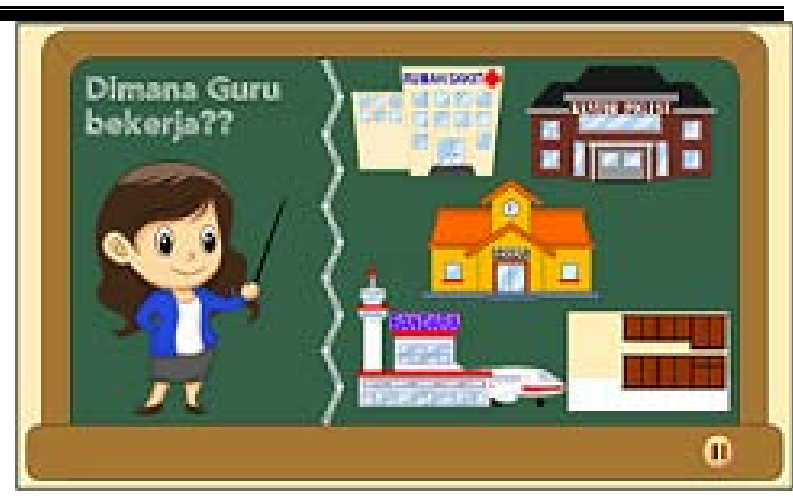

Figure 4.8Gameplay Display Mini Game Profession Category

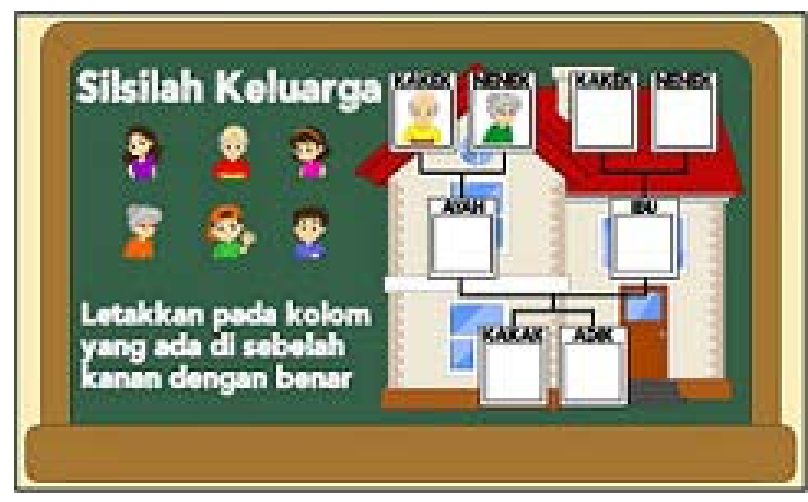

Figure 4.9Gameplay Display Mini Game Family Category

\subsection{Game Programming "Smart}

\section{Puzzle"}

Game programming "Smart Puzzle" uses a Construct 2. Here are some examples of game programming of "Smart Puzzle", namely:

\subsubsection{GUI Programming in Option Menu Category \\ Below is the programming option} menu category on the "Smart Puzzle" game :

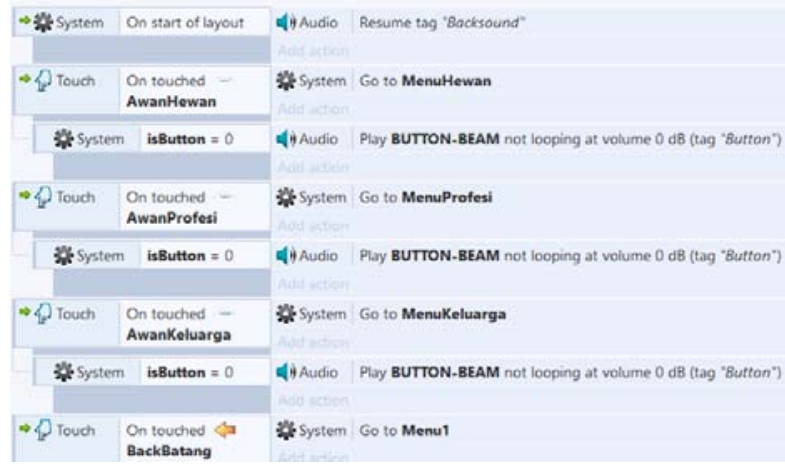

Figure 4.10Programming Option Menu Category 


\subsubsection{Gameplay Programming}

At each stage, the programming is used almost the same. The difference is the position or the point where those letters are placed. As an example, below is the programming category of animals on the "Smart Puzzle" game of the deer:

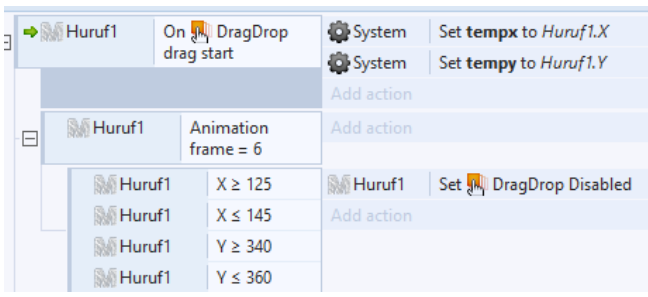

Figure 4.11 Position Letter Program

Figure 4.13 shows programming which ensures the letter sticked to correspond to the coordinates. So when one letter is placed in the $\mathrm{X}$ and $\mathrm{Y}$ coordinates correctly, then the letters will stick to the coordinates and could not be moved again.

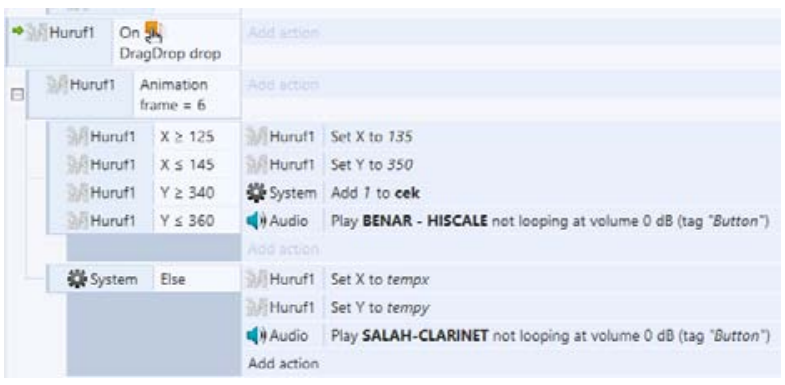

Figure 4.12Programming Check Letter

Figure 4.14 programming is used to check for the correct letter and the letters which are wrong placed.

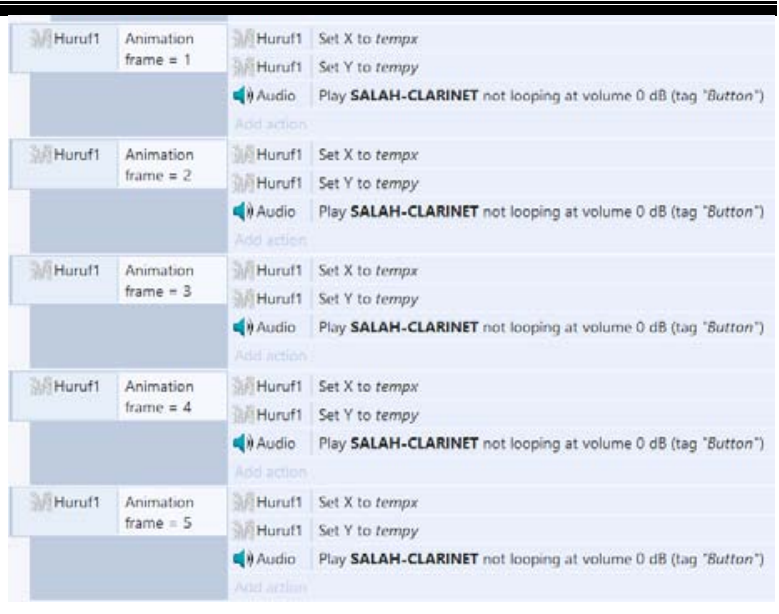

Figure 4.13Programming The Wrong Letters

Figure 4.15 shows programming which is used to return the wrong letter.

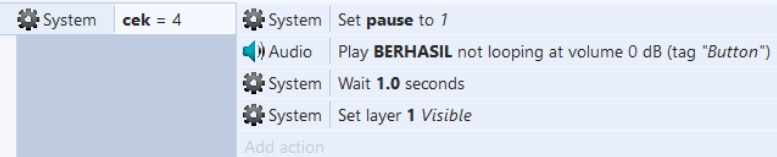

Figure 4.14Programming Check

Figure 4.16 shows the programming of the variable check. A check is used to count the number of letters. When the letter is already qualified in accordance with the value of cheques that has been specified then the layer will appear successfully.

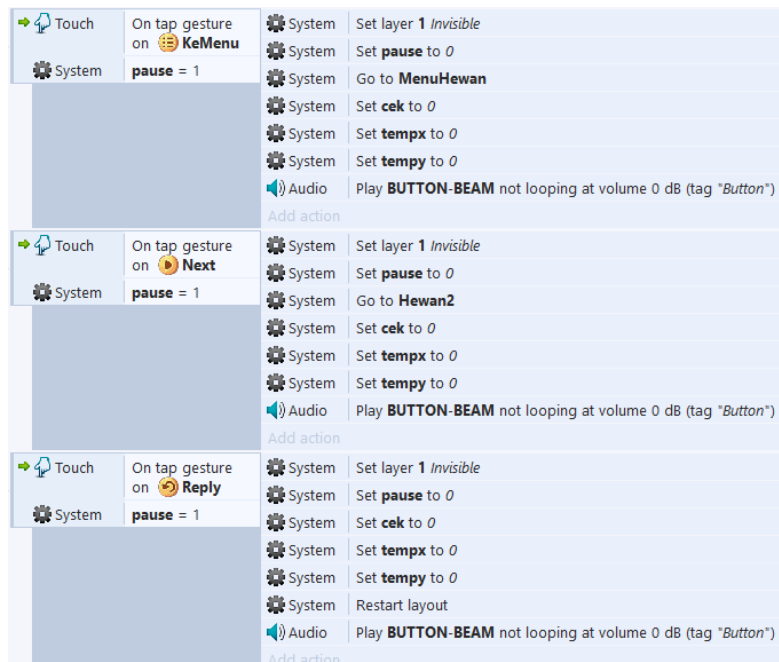

Figure 4.15 Successful Layer Programming

\subsection{Results}

Research is done through the method of disseminating a questionnaire. This 
questionnaire is used to know their child's reading skill level after playing "Smart Puzzle" game. The results of the previous research is the percentage of time the child has not played a " Smart Puzzle" game yet. The results of this research are discussed regarding the percentage of time the children has been playing a game of "Smart Puzzle". Research was conducted with 30 respondents who are the parents with kindergarten children. The percentage of children who have not been able to get to know the letters has decreased from 20\% to 3\% after playing this "Smart Puzzle" game. The percentage of children who already know the letters increases from $80 \%$ to $97 \%$ after playing this "Smart Puzzle" game. The percentage of children who are unable to read one word has also decreased from $53 \%$ to $23 \%$. The percentage of children who can already read one word after playing a game of "Smart Puzzle" increases from $47 \%$ to $77 \%$. $87 \%$ of children can sort out the letters correctly and $13 \%$ children are still unable to compose the letters correctly. Thus, the "Smart Puzzle" games can help children to recognize letters, learn to read a single word and can help children to learn to compose the letters correctly.

\section{CONCLUSION}

The conclusion of this study is as follows.

1. "Smart Puzzle" Games are educational games used as tools to teach reading to kindergarten children using a game concept of devised letters tailored to different images in each part of it.

2. "Smart Puzzle" Games are made to meet the needs of parents who have children at KINDERGARTEN. This educational game is used as a medium of instruction to their children.

3. "Smart Puzzle" Games can boost children's interest in reading using the interesting game and they can easily be played by children.

\section{ACKNOWLEDGMENT}

Septyana Hardianti Yunanto is

Scholarship grantee from education and culture ministry of Indonesian Republic.

\section{REFERENCES}

[1] Dr. Dr Chris McComrick, "Usia berapa seharusnya Anak Anda mulai membaca?”, [Online]. Tersedia : http://www.ef.co.id/englishfirst/english study/tipsbelajarbahasainggris/kapananak-mulai-membaca.aspx [Diakses : 04 Septembar 2015].

[2] W. Pajarwati, "UPAYA MENINGKATKAN KEMAMPUAN MEMBACA AWAL DENGAN MENGGUNAKAN PENDEKATAN WHOLE LANGUAGE PADA ANAK KELOMPOK B2 TK WARU 01 KEBAKKRAMAT TAHUN AJARAN 2011/2012.” Universitas Muhammadiyah Surakarta, 2011.

[3] L. Ade Sessiani, "Pengaruh Metode Multisensori dalam Meningkatkan Kemampuan Membaca Permulaan pada Anak Taman Kanak-kanak (Studi Eksperimental di TK ABA 52 Semarang)." Universitas Diponegoro, 2007.

[4] R. Delima, N. K. Arianti, and B. Pramudyawardani, "Identifikasi Kebutuhan Pengguna Untuk Aplikasi Permainan Edukasi Bagi Anak Usia 4 sampai 6 Tahun,” J. Tek. Inform. dan Sist. Inf., vol. 1, no. 1, 2015.

[5] K. A. Harras, "Hakekat Membaca." 2011.

[6] I. G. P. Astawa, A. A. I. N. Marhaeni, and G. R. Dantes, "PENGARUH PEMBELAJARAN INKUIRI BERBASIS BUKU CERITA TERHADAP MINAT BACA DAN HASIL BELAJAR MEMBACA BAHASA INDONESIA PADA SISWA KELAS V SD GUGUS III KECAMATAN ABANG,” J. Pendidik. Dasar, vol. 5, no. 1, 2015.

[7] Syah, Muhibbin, "Psikologi Pendidikan dengan Pendekatan Baru,” Bandung: Rosda, 2004. 
"Smart Puzzle" Game Helping Children Learn to Read

[8] Tamyit, "PENINGKATAN KEMAMPUAN MEMBACA

LANCAR DENGAN MEDIA KARTU HURUF DALAM PEMBELAJARAN

BAHASA INDONESIA PADA SISWA KELAS SATU SEKOLAH DASAR,” 2010.

[9] "Pengrtian Game Menurut Para ahli", Wired, 29 Desember 2014, [Online]. Tersedia http://www.mandalamaya.com/pengerti an-game-menurut-para-ahli/ [Diakses : 11 September 2015].

[10] Marlia, Khusnul, "Mengenal CoreDraw Multimedia”, Wired, 20 November 2014, [Online]. Tersedia : http://arjanpranjic.blogspot.co.id/2013/ 10/mengenal-coreldrawmultimedia.html [Diakses : 25 Mei 2016].
[11] Rahmansyah, Arief, “ Pengenalan Interface Construct 2 (Part 1)”, Wired, 22 Januari 2014, [Online]. Tersedia : https://ariefrahmansyah.wordpress.com/ 2014/01/22/pengenalan-interfaceconstruct-2-part-i/] [Diakses : 11 September 2015].

[12] Clark Aldrich, Learning Online with Games, Simulations, and Virtual Worlds: Strategies for Online Instruction. San Francisco: JosseyBass, 2009.

[13] "Pengrtian Game Menurut Para ahli", Wired, 29 Desember 2014, [Online]. Tersedia

http://www.mandalamaya.com/pengerti an-game-menurut-para-ahli/ [Diakses : 11 September 2015]. 